\title{
Eritrositlerde Oksidatif Stres Oluşumunda Rol Oynayan Özgül Mekanizmalar ve Koruyucu Antioksidan Sistemler
}

\section{Specific Mechanisms and Protective Antioxidant Systems Playing Role in Occurring Oxidative Stress in Erythrocytes}

\author{
Onur ELMAS ${ }^{1}$, Sinem ELMAS ${ }^{2}$
}

${ }^{1}$ Muğla Sıtkı Koçman Üniversitesi, Tıp Fakültesi, Fizyoloji Anabilim Dalı, Muğla

${ }^{2}$ Muğla Sitkı Koçman Üniversitesi, Fen Fakültesi, Biyoloji Bölümü, Muğla

\section{Öz}

Eritrositler, kanda sayıca en fazla bulunan ve asıl görevi solunum gazlarını taşımak olan özelleşmiş hücrelerdir. Reaktif oksijen türleri, lipitlerin, nükleik asitlerin, proteinlerin, șekerlerin veya sterollerin oksidasyonuna neden olarak eritrositlerin veya öncüllerinin yapı ve işlevini bozabilir. Özellikle hücre zarlarının oksidasyonu eritrositlerde kırılganlığın artmasına ve dolayısıyla ömürlerinin kısalmasına neden olur. Eritrositler, sitoplazmalarında bulundurdukları hemoglobin sayesinde bol miktarda oksijeni bağlayabilmelerine rağmen, oksijeni enerji üretiminde kullanamazlar. Birçok dokuda oksidatif stresin asıl kaynağı mitokondri ve peroksizomlardır, ancak eritrositlerde bu organeller bulunmaz. Eritrositlerde oksidasyonu katalizleyen bu organellerin bulunmamasına rağmen, organizmada oksidatif stresten en fazla etkilenen hücrelerin başında eritrositler yer almaktadır. Eritrositlerde meydana gelen oksidatif stresin temelini içerdikleri hemoglobin ve demir atomu olușturur. Bu derlemede, eritrositlerin maruz kaldığı özgül oksidatif stres mekanizmalarının, hücrede meydana gelen değisikliklerin ve bu stresi alt edebilecek hücre içi koruyucu sistemlerin neler olduğu sistematik olarak tartışılmıştır. Anahtar Kelimeler: Eritrosit, Kırmızı Kan Hücresi, Oksidatif Stres

\section{Giriş}

\section{Oksidatif Stres}

Fizyolojik koşullarda oksidanlar ile antioksidanlar arasında bir denge vardır. Hücrenin yaşaması ve fonksiyonlarının devamı için bu dengenin sağlanması gerekmektedir. Oksidatif stres, oksidanlar ve antioksidanlar arasındaki dengesizlik sonucu ortaya çıkan durumdur. Reaktif oksijen türleri (reactive oxygen species, ROS), oksijen molekülünün kısmi indirgenmesinden oluşan reaktif molekülleri ve serbest radikalleri tanımlamak için kullanılan bir terimdir (1). ROS'ların artması lipitlerin, nükleik asitlerin, proteinlerin, şekerlerin ve sterollerin oksidasyonuna neden olabilir. Bu durum hücrenin yapı ve işlevinin bozulmasıyla sonuçlanır.

ROS'lar, ultraviyole 1şınlar, iyonize radyasyon, sigara, hava kirliliği gibi ekzojen maruziyetlerden

\begin{tabular}{ll}
\hline & ORCID No \\
Onur ELMAS & 0000-0002-8380-0999 \\
Sinem ELMAS & 0000-0002-2872-9990 \\
& \\
Başvuru Tarihi / Received: & 18.11 .2020 \\
Kabul Tarihi / Accepted : & 11.12 .2020 \\
Adres / Correspondence & Onur ELMAS \\
Muğla Sitk1 Koçman & Üniversitesi Tıp Fakültesi Fizyoloji \\
Anabilim Dalı, Muğla & \\
e-posta / e-mail & onurelmas@ outlook.com \\
\hline
\end{tabular}

\section{Abstract}

Erythrocytes are specialized cells that are the most abundant in the blood and whose main task is to carry respiratory gases. Reactive oxygen species can disrupt the structure and the function of erythrocytes or their precursors by causing oxidation of lipids, nucleic acids, proteins, sugars, or sterols. In particular, oxidation of cell membranes causes increased fragility in erythrocytes and thus shortening their lifespan. Erythrocytes, despite their ability to bind abundant oxygen due to the hemoglobin they contain in their cytoplasm, they cannot use oxygen in energy production. The main source of oxidative stress in many tissues are mitochondrias and peroxisomes, but these organelles are not found in erythrocytes. Despite the absence of these organelles catalyzing oxidation in erythrocytes, erythrocytes are at the head of the cells most affected by oxidative stress in the organism. The basis of oxidative stress occurring in erythrocytes are hemoglobins and iron atoms. In this review, the specific oxidative stress mechanisms that erythrocytes are exposed to, the changes that occur in the cells, and the intracellular protective systems that can overcome this stress are systematically discussed.

Keywords: Erythrocyte, Oxidative Stress, Red Blood Cell kaynaklanabileceği gibi, hücre metabolizması sırasında, endojen olarak da üretilebilir (2). Hücrelerde en fazla endojen ROS üretimi, mitokondri ve peroksizom faaliyetleri sırasında, lipooksijenaz, NADPH oksidaz ve sitokrom p450 gibi enzimlerin aktivitelerinin arttığı durumlarda görülür (3). Hücreler oksidatif strese maruz kaldıklarında, oksidan etkilere karşı kendilerini korumaya ve redoks dengesini eski haline getirmeye çalışır. Bu hücresel aktivite sırasında, savunma enzimlerini, transkripsiyon faktörlerini ve yapısal proteinleri kodlayan genlerin aktivasyonu görülür (4).

ROS'lar, hücresel savunma mekanizmaları zayıfladığında, özellikle lipit ve proteinlerin hasar görmesine, sinyal iletim yollarını modüle ederek, gen ekspresyonundaki değişikliklere ve ardından sonuçta yaşlanmaya veya apoptoza neden olan hücresel tepkilere neden olur (5). Lipit peroksidasyonu, ROS'lar tarafindan hızlandırılan bir serbest radikal zincir reaksiyonudur. Hücre zarları, ekstrinsik proteinlere sahip çift katman fosfolipit yapılardır ve lipit oksidasyonunun açık hedefleridir. Hücre zarındaki peroksidasyon, lipit faz yüzey yükünün polaritesini artırarak lipitlerin moleküler hareketliliğinde azalmaya, -SH (tiyol) gruplarının sayısını azaltarak protein oligomerlerinin oluşumuna ve termo-denatürasyona karşı dirençte azalmaya neden olur (6). ROS'lar, hücre zarıyla ilişkili 
olmayan proteinleri de okside edebilir. ROS maruziyetinde proteinlerin amino asit kalıntı yan zincirlerinin oksidasyonu, protein-protein çapraz bağlantılarının oluşumu ve protein omurgasının oksidasyonu görülebilir (7). Bu olayların bir sonucu olarak membran akışkanlığında, proteinlerin ve enzimlerin spesifik işlevlerinde bozulmalar görülebilir (8).

Oksidatif stresin canlı organizmada meydana getirdiği etkileri ve bu etkilerin hastalıklarla ilişkisini inceleyen çalışmalar popülerliğini uzun süredir korumaktadır (9-14). Organizmada oksidatif stresten en fazla etkilenen hücrelerin başında eritrositler yer almaktadır (6). $\mathrm{Bu}$ nedenle, eritrositlerin maruz kaldığı özgül oksidatif stres mekanizmalarının ve bu stresi alt edebilecek hücre içi koruyucu sistemlerin iyi bilinmesi, eritrosit fonksiyonlarının etkilendiği birçok hastalığın patofizyolojisinin anlaşılmasında fayda sağlayacaktır.

\section{Eritrositler}

Eritrositler, kanda en fazla bulunan ve organizmadan en kolay izole edilebilen hücre türüdür. İçerdikleri hemoglobin sayesinde solunum gazlarınının kanda taşınmasını sağlarlar (15). Membranlarının elastik olması sayesinde, şekil değiştirerek, kendi çaplarından daha küçük çaplı kılcal damarlardan bile rahatça geçebilirler. Olgun eritrositler, 8 mikron çapında ve 2 mikron kalınlığında, bikonkav disk şeklinde olup, ortalama 120 günlük bir ömre sahiptir (16). Yaşlanan eritrositler retikülo-endotelyal sistem tarafından dolaşımdan uzaklaştırılırken, kaybedilen miktar kadar, düzenli olarak kemik iliğinde hematopoetik kök hücreden üretilir (17). Kök hücreden olgun eritrosite giden farklılaşmada, eritroid hücrelerde hemoglobin üretimi giderek artar. Eritroid hücreler çekirdek, ribozom ve mitokondri gibi organelleri kaybederek olgun eritrositlere dönüşürler. $\mathrm{Bu}$ nedenle eritrositler protein sentezi ve oksidatif fosforilasyon yapamazlar (18).

Olgun eritrositlerin sitoplazmasında bol miktarda hemoglobin molekülü bulunur. Hemoglobin, her biri +2 değerli demir atomu bulunduran 4 hem molekülünün ve 4 globulin zincirinin birleşmesiyle oluşmuş büyük bir proteindir. Yetişkin eritrositlerinde en fazla bulunan hemoglobin türü hemoglobin A'dır ve globülin yapısında 2 adet alfa ve 2 adet beta globülin zinciri bulunur. Oksijen, hemoglobin molekülünde demir atomuna bağlanarak taşınır. Bu şekilde her bir hemoglobin molekülüne bağlanmış şekilde 4 oksijen molekülü, yani 8 oksijen atomu taşınır (19).

Çekirdeğinin bulunmaması nedeniyle, olgun eritrositlerin protein-enzim sentezleme yeteneği yoktur. Bu nedenle kırmızı kan hücresi, yaşam ömrünü sürdürecek kadar sınırlı bir metabolizma kapasitesine sahiptir (18). Eritrositlerin bu kisitlı metobolizmaları onları oksidatif stres maruziyeti gibi etkilere duyarlı yapar.

Eritrositler bol miktarda oksijen taşımalarına rağmen, mitokondriye sahip olmadıklarından dolayı enerjilerini sadece anaerobik fosforilasyondan sağlar. Eritrosit dışındaki diğer vücut hücrelerinde en önemli ROS kaynakları mitokondriyal oksidatif fosforilasyon ve peroksizom faaliyetleridir (20). Bu organellerin bulunmaması oksidatif stres yönünden eritrositlere bir avantaj sağlar, ancak, prooksidan etkilere sahip demir içeren hemoglobin taşımaları onları dezavantajlı duruma düşürür. $\mathrm{Bu}$ derlemede, eritrositlerde oksidatif stres oluşumunda rol oynayan özgül oksidatif stres mekanizmalarının neler olduğu ve bu mekanizmalarda üretilen oksidanların antioksidan sistemler tarafindan nasıl bertaraf edildiği tartışılacaktır.

\section{Eritrositlerde Endojen ROS Kaynakları}

a) Hemoglobinin oksidatif denatürasyonu

Oksijenli hemoglobin, diğer ismiyle oksihemoglobin [oksiHb, $\mathrm{Hb}\left(\mathrm{Fe}^{+2}\right) \mathrm{O}_{2}$ ] nispeten kararlı bir molekül olarak kabul edilmesine rağmen, fizyolojik olarak, günde \%0.5-3’ü kendiliğinden methemoglobine [metHb, $\left.\mathrm{Hb}\left(\mathrm{Fe}^{+3}\right)\right]$ okside olur (21). Bu otooksidasyon, hipoksik koşullarda daha belirgindir (22).

$$
\mathrm{Hb}\left(\mathrm{Fe}^{+2}\right) \mathrm{O}_{2} \rightarrow \mathrm{Hb}\left(\mathrm{Fe}^{+3}\right)+\mathrm{O}_{2}^{\cdot-}
$$

Hemoglobinin otooksidasyonu ile üretilen süperoksit iyonları, spontan veya enzim güdümlü dismutasyon yoluyla hızla hidrojen perokside dönüştürülür $(22,23)$.

$$
2 \mathrm{O}_{2}^{\cdot-}+2 \mathrm{H}^{+} \rightarrow \mathrm{H}_{2} \mathrm{O}_{2}+\mathrm{O}_{2}
$$

$\mathrm{H}_{2} \mathrm{O}_{2}$, hem oksiHb hem de metHb ile reaksiyona girerek sirasiyla ferril $\mathrm{Hb} \quad\left[\mathrm{Hb}\left(\mathrm{Fe}^{+4}\right)=\mathrm{O}\right]$ ve oksiferrilHb $\left.\left[{ }^{\bullet} \mathrm{Hb}\left(\mathrm{Fe}^{+4}\right)=\mathrm{O}\right]\right)$ haline dönüștürür $(22,23)$. Oksiferril Hb, hidroksil radikalleriyle $\left({ }^{\bullet} \mathrm{OH}\right)$ kıyaslandığında daha güçlü oksidasyon yeteneğine sahiptir (24).

$$
\begin{gathered}
\mathrm{Hb}\left(\mathrm{Fe}^{+2}\right) \mathrm{O}_{2}+\mathrm{H}_{2} \mathrm{O}_{2} \rightarrow \mathrm{Hb}\left(\mathrm{Fe}^{+4}\right)=\mathrm{O}+\mathrm{H}_{2} \mathrm{O}+\mathrm{O}_{2} \\
\mathrm{Hb}\left(\mathrm{Fe}^{+3}\right)+\mathrm{H}_{2} \mathrm{O}_{2} \rightarrow \cdot \mathrm{Hb}\left(\mathrm{Fe}^{+4}\right)=\mathrm{O}+\mathrm{H}_{2} \mathrm{O}
\end{gathered}
$$

FerrilHb ve oksiferrilHb daha sonra $\mathrm{H}_{2} \mathrm{O}_{2}$ ile reaksiyona girerek metHb oluşumunu artırırlar $(22,23)$.

$$
\begin{aligned}
& \mathrm{Hb}\left(\mathrm{Fe}^{+4}\right)=\mathrm{O}+\mathrm{H}_{2} \mathrm{O}_{2} \rightarrow \mathrm{Hb}\left(\mathrm{Fe}^{+3}\right)+\mathrm{H}_{2} \mathrm{O}+\mathrm{O}_{2}^{\cdot-} \\
& \cdot \mathrm{Hb}\left(\mathrm{Fe}^{+4}\right)=\mathrm{O}+\mathrm{H}_{2} \mathrm{O}_{2} \rightarrow \mathrm{Hb}\left(\mathrm{Fe}^{+3}\right)+\mathrm{H}_{2} \mathrm{O}+\mathrm{O}_{2}
\end{aligned}
$$

Tüm bu reaksiyonlar sonunda eritrosit hücresinde metHb ve ROS'lar giderek $\operatorname{artar}(25)$. 
Hem molekülü, oksiHb'e kıyasla MetHb'de globülinlere daha düşük bir afiniteye sahiptir; bu da onun globülinlerden ayrışmasına artmasına neden olur (26). Ortamdaki $\mathrm{H}_{2} \mathrm{O}_{2}$, serbest hem ile reaksiyona girerek hemin yıkımına ve demirinin serbestleşmesine neden olur (27). Ek olarak, ferrilHb'nin $\mathrm{H}_{2} \mathrm{O}_{2}$ ile reaksiyonu sonucu üretimi $\operatorname{artan} O_{2}^{\bullet-}$, hem yıkımının artmasina neden olur (27).

\section{b) Hem ve demir}

Demirin gerek serbest formu, gerekse hem veya hemoglobine bağlı formu, son derece reaktif hidroksil radikalleri üreten Haber-Weiss döngüsünde bir Fenton Reaktifi olarak hareket eder (28).

$$
\mathrm{Fe}^{+2}+\mathrm{H}_{2} \mathrm{O}_{2} \rightarrow \mathrm{Fe}^{+3}+\cdot \mathrm{OH}+\mathrm{OH}^{-}
$$

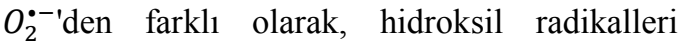
enzimatik olarak elimine edilemez ve bu nedenle oksidatif hasarlanmaya sebep olur (29). Demir şelatörleri ile serum demir miktarının azaltılması sonucu eritrosit zarlarındaki lipit peroksidasyonunun azalması, ROS artışına bağlı oksidan hasarlanmanın kısmen demire bağlı olduğunu göstermektedir (30).

Hem molekülü, demir içeren hidrofobik bir moleküldür. Serbest hem, membran lipitlerine ve proteinlere etki ederek onların oksidasyonuna neden olabilir (31). Dolaşımdaki hem, LDL'nin oksidasyonuna neden olarak lipit hidroperoksitlerini artırır (32). Bunun sonucu olarak endotel hücrelerinde sitotoksik etkiler görülebilir. Hem ayrıca, nükleer faktörü- $\kappa \mathrm{B}^{\prime} \mathrm{yi}(\mathrm{NF}-\kappa \mathrm{B})$ aktive etme yeteneğine sahiptir. NF- $\kappa \mathrm{B}$ reseptörlere, enzimlere ve transkripsiyon faktörlerine bağlanarak inflamasyonu artırır (33). Dahası, hem molekülü, DNA'y1 oksidatif olarak denatüre edebilir, kaspazları ve katepsinleri aktive edebilir, mitokondriyal işlevi bozabilir ve glutatyon redüktaz gibi antioksidan enzimlerin aktivitesini azaltabilir $(22,34)$.

\section{c) Nikotinamid adenin dinükleotit fosfat (NADPH) oksidaz}

Eritrositlerde ROS'lar enzimatik olarak NADPH oksidaz ile de üretilebilir. NADPH oksidaz, bir elektronu NADPH'den oksijene aktararak süperoksit serbest radikalinin üretimini katalize eden bir enzimdir. $\mathrm{Bu}$ işlem sırasında $\mathrm{O}_{2}$ hücre dışından hücre içine taşınırken $\mathrm{H}^{+}$hücre dışına aktarılır (35).

$$
\mathrm{NADPH}+2 \mathrm{O}_{2} \underset{+\mathrm{H}^{+}}{\stackrel{N A D P H \text { Oksidaz }}{\longleftrightarrow}} \mathrm{NADP}^{+}+2 \mathrm{O}_{2}^{\circ-}
$$

Eritrositlerde NADPH oksidaz aktivitesi Protein kinaz C, Rac GTPaz ve $\mathrm{Ca}_{2}{ }^{+}$sinyalleri ile düzenlenmekte ve bu aktive TGC $\beta 1$ ve endotelin1 sitokinleri ile artırılabilmektedir (35).
Eritrositlerde Oksidatif Strese Bağlı Değişiklikler

a) Fosfolipit asimetrisi, fosfatidilserinlerin sergilenmesi ve eriptoz

Hemoglobinin tam olmayan oksijenasyonu, hemoglobinde yapısal değişiklikler oluşmasına neden olur. $\mathrm{Bu}$ olay sadece artmış otooksidasyon sonucu değil, aynı zamanda hemoglobinin hücre membranına bağlanmasından kaynaklanmaktadır $(36,37)$. Bu nedenle, kısmen oksijenli hemoglobin, özellikle kararsız ise, eritrosit membranında üretilen ROS'ların çoğundan sorumludur (38). Hücre zarında bulunan ROS'lar, sitoplazmik antioksidan sisteme kolayca erişemediğinden, mevcut sınırlı membran antioksidanlarını (örneğin, $\mathrm{E}$ ve $\mathrm{C}$ vitaminleri, glutatyon peroksidaz (Gpx) ve peroksiredoksin (Prx) gibi) hizla alt ederek, membran lipitlerini ve proteinlerini kolayca okside edebilir (38-43). Lipitlerin peroksidasyonu ve proteinlerin oksidasyonu, membran lipit organizasyonunun bozulmasına neden olur $(39,44)$. Eritrosit işlevi için plazma membranı çok önemlidir. Eritrositler, şekil değiştirebilme yeteneği sayesinde küçük kılcal damarlar içinden rahatça geçebilir ve böylece oksijeni dokulara verimli bir şekilde taşıyabilir (45).

Membran fosfolipitlerinin fizyolojik asimetrisinin bozulması, membran yüzeyinde fosfatidilserinin açığa çıkmasına neden olur (46). Fosfatidilserin, makrofajlardaki süpürme reseptörleri tarafından tanınan bir sinyaldir (47). Fosfatidilserinin dış membran yüzeyinde sergilenmesi sonucunda eritrositler makrofajlar tarafından fagositoza uğrar.

Eriptoz, yaşlı eritrositlerde ortaya çıkan bir nevi apoptoz türüdür. Oksidatif stres, hiperosmolarite, enerji tükenmesi, ağır metallere maruz kalma, artan $\mathrm{Ca}^{2+}$ konsantrasyonu, kaspazlar ve protein kinaz $\mathrm{C}$ (PKC) ve p38 MAPK (mitojenle aktifleştirilen protein kinaz) gibi çeşitli kinazların bozulmuş aktivitesi veya ksenobiyotikler gibi çeşitli faktörlere bağlı olarak başlatılabilir (48). Apoptoz gibi, eriptoz da hücre büzülmesi, membran kabarcıklanması, proteazların aktivasyonu ve diş membranda fosfatidilserinlerin açığa çıkması gibi süreçlerle karakterizedir.

\section{b) Hemikrom oluşumu, bant-3 oksidasyonu ve yaşlanma}

Üçüncül ve dördüncül yapısı etkilenerek denatüre hale gelmiş hemoglobinler ile fazla miktarda üretilmiş serbest globin zincirleri eritrosit membranına etki ederek yapısal ve işlevsel değişikliklere neden olabilir. Kararsız hemoglobinler oksidasyona uğramaya, denatüre olmaya ve böylece hücre zarında hemikrom şeklinde çökmeye eğilimlidir (49,50). Hemikrom, histidin kompleksi oluşturmuş, daha kararlı demir taşıyan metHb formudur.

Hemikromlar, bir transmembran proteini olan bant-3'ün sitoplazmik tarafina bağlanabilirler. Bant- 
3 anyon transport proteini, tüm eritrositlerin membranlarında bulunur ve klorürün $\left(\mathrm{Cl}^{-}\right)$ bikarbonat $\left(\mathrm{HCO}_{3}{ }^{-}\right)$ile yer değiştirmesinde görev alır. Hemikromlar, bant-3 proteinine disülfit bağlarıyla bağlanır. Hemikromlarca aktive edilen bant-3 proteinin sitoplazmik bölgesi, tirozin kinazlar ile fosforile olur (49,51). Bu durum bant-3'ün kümelenmesine ve ankirin ile olan bağlantısının bozulmasına yol açar. Bant-3 proteininin hücre iskeletini oluşturan proteinlerden ayrılmasıyla, plazma membranında mikrovezüküller oluşur (52,53). Bant-3/hemikrom kümeleri anti-bant-3 antikorları tarafından tanınır. Anti-bant-3 antikorları, bant-3/hemikrom kümeleri için yüksek bir afiniteye sahiptir. Antikorlar bağlandıktan sonra, kompleman sistemini aktive ederler ve makrofajların eritrosit fagositozunu tetikler $(52,54)$. Anti-bant-3 antikorlarının bağlanması ve kompleman aktivasyonu, yaşlanan eritrositlerin temizlenmesinde önemli rol oynar $(52,55)$. Bant-3 proteinin bir diğer işlevi, glikolitik enzimleri membrana bağlayarak glikoliz ve pentoz fosfat yolu arasındaki glikoz akışını düzenlemektir. Glikolitik enzimlerin, oksitlenmiş bant-3'ten ayrılması, glikolizin aktivasyonuna yol açarken, pentoz fosfat yolunun baskılanmasına, yani NADPH üretiminin azalmasina neden olur (56). NADPH, GSH ve Prx'in önemli bir indirgeyici ajanıdır; NADPH oksidatif strese karşı koruma sağlar (57). Sonuç olarak, NADPH seviyelerindeki azalma, eritrositlerin antioksidan kapasitesini azaltır ve oksidatif stresi daha da şiddetlendirir.

\section{c) Hücre iskeletinde bozulma}

Oksidatif stres, sadece hücre membranını değil, aynı zamanda hücre iskelet proteinlerini de etkilemektedir. Beatty Proteini olarak da bilinen Protein 4.1, hücre zarının mekanik stabilitesini sağlamak ve hücrenin şekil değiştirebilme kabiliyetini düzenlemek üzere spektrin ve aktin ile etkileşim içindedir. Oksidatif stres, Protein 4.1'in spektrine bağlanmasını ve spektrin-aktin ilişkisini düzenleme yeteneğini azaltır (58). Spektrin, ROS'ların ana hedefidir. Spektrinin oksidasyonu, aktin gibi hücre iskelet proteinlerinin veya protein 4.1 gibi membran ile hücre iskeletini köprüleyen proteinlerin etkileşiminde bozulmaya yol açar (58). $\mathrm{Bu}$ olay, membran ve hücre iskeleti arasındaki etkileşimde stabilitenin bozulmasına ve dolayısıyla kırılganlığın artmasına neden olur.

Bunlara ek olarak, ROS üretimi ile ilişkili NADPH oksidaz enziminin aktivitesini artıran PKC gibi hücre içi haberciler, aynı zamanda bir membran proteini olan $\alpha$-Adducin'in fosforilasyonunu da artırırlar $(35,59) . \quad \alpha$-Adducin'in fosforilasyonu, spectrin'in aktinden ayrılmasına neden olarak hücre iskeletinin stabilitesinin bozulmasına katkıda bulunur. d) ROS'un bir sinyal molekülü olarak hemolizi tetiklemesi

ROS'lar, sadece oksitleyici moleküller olarak işlev görmekle kalmaz, aynı zamanda protein tiyollerini okside ederek transkripsiyon faktörlerinin, membran kanallarının ve metabolik enzimlerin aktivitelerini etkileyebilir ve böylece sinyal yolaklarına entegre olabilir $(60,61)$. ROS, Kaspaz-3 aktivasyonuna neden olur $(62,63)$. Kaspaz-3, normal olarak, eritropoez sirasinda üretilen bir enzimdir. Eritropoetin seviyesi düşük olduğunda hücre iskeleti ve DNA yapısında bulunan GATA-1, Tal-1 ve proteinleri parçalayarak programlanmış hücre ölüm sürecini başlatır $(64,65)$. Kaspaz-3'ün ROS ile aktive olması, bant-3 proteinin sitozolik proteinler ve hücre iskeleti ile ilişkilisini bozar (66). Membran yapısının bozulması, fosfatidilserinlerin diş membran yüzeyinde sergilenmesine neden olur (67).

Oksidatif stresin $\mathrm{Ca}^{2+}$ ATPaz pompasının inhibisyonuna ve $\mathrm{Ca}^{2+}$ geçirgen selektif olmayan katyon kanallarının aktivasyonuna neden olduğu gösterilmiştir $(47,68)$. Eritrositlerde hücre içi $\mathrm{Ca}^{2+}$ artışı kalpain, transglutaminaz-2 ve kaspazların aktivasyonuna yol açarak hücre iskeletindeki proteinlerin parçalanmasına neden olur (69). Buna ilave olarak, artan hücre içi $\mathrm{Ca}^{2+}$, fosfotirozin fosfatazı inhibe ederek bant-3 fosforilasyonunu artırır ve flippaz aktivitesini azaltır (70,71). Flippaz enzimi hücre zarını oluşturan iki yaprakçık arasındaki fosfolipit moleküllerinin hareketine yardımcı olmaktan sorumludur (enine difüzyon veya "flip-flop" geçişi olarak da bilinir). Bant-3 fosforilasyonunun artması ve flippaz aktivitesinin azalması membran yapısının bozulmasına, fosfatidilserinlerin açığa çıkmasına ve sonuçta eriptoza neden olur.

Hücre içi $\mathrm{Ca}^{2+}$ artışı, Gardos adı verilen kanalın aktivasyonuna, böylece hücre içi $\mathrm{K}^{+}$'nın hücre dışına kaymasına neden olur. Katyon homeostazındaki bu değişiklikler, suyun hücre dişına çıkmasına ve dolayısıyla eriptoz ile sonuçlanan hücre büzülmesine yol açar (48,72-74). Oksidatif stresin, K-Cl kotransporter (KCC) aktivitesini de etkileyebileceği gösterilmiştir (75,76). Artmış KCC aktivitesi, $\mathrm{K}^{+}$'nın, eritrositlerden daha fazla çıkmasına neden olur. $\mathrm{K}^{+}$'nın artan çıkışı, membran boyunca $\mathrm{K}^{+}$ gradyanını azaltabilir ve membran depolarizasyonuna yol açabilir. $\mathrm{Bu}$ durum, $\mathrm{Cl}^{-}$'un hücre içine girişine ve sitoplazmanın ozmolaritesinin artmasına, takiben hücre içine su girmesine neden olur. Aşırı deplazmoliz, hücre zarı bütünlüğünü bozar ve eritrositlerin hemolizine neden olur (77). Aşırı oksidatif yaralanma sonucu, eritrositler yaşlanma veya eriptoz gibi kontrollü bir mekanizma ile temizlenemeden hemolize uğrayabilir (25).

\section{e) Oksidatif stres ve etkisiz eritropoez}

Fazla miktarda eşleşmemiş $\alpha$-globinlerin varlığında eritropez bozulur. $\mathrm{Bu}$ duruma genetik 
hemoglobin yapım bozukluklarında sıkça karşılaşılır (22,78,79). Eşlenmemiş $\alpha$-globinler, yüksek miktarda ROS üreterek, hemin ve demirin oksidasyonuna ve çökelmesine neden olur (22). Daha önce bahsedildiği gibi, bu moleküller, eriptoz ile sonuçlanan bant-3 kümelenmesine ve fosfatidilserinlerin sergilenmesine neden olur $(46,52)$. Hemoglobin yapım bozukluklarında, eriptozunun bir göstergesi olan aktif makrofajlar kemik iliğinde sayıca artmaktadır $(80,81)$ Bu durum oksidatif stresi ve $\alpha$-globin çökelmesini teşvik eden, büyüme farklılaşma faktörü 11 (GDF11) tarafından da indüklenmektedir (82).

\section{f) Eritroid proliferasyon ve hızlandırılmış farklılaşma}

Kemik iliğinde artmış etkisiz eritropoez veya aşırı hemoliz, anemiye yol açabilir. Anemi, doku hipoksisine ve eritropoetin üretiminde artışa neden olur. Bu durum, hızlandırılmış eritroid farklılaşması ve proliferasyonu ile karakterize medüller ve ekstramedüller eritropoeze yol açar $(81,83)$. Eritroid öncüllerinin hızlı çoğalması ve farklılaşması sırasında, aerobik solunumda, dolayısıyla ATP seviyelerinde bir artış olur (84). $\mathrm{Bu}, \mathrm{Ca}^{2+}$ pompalarının aktivasyonuna ve hücre içi $\mathrm{Ca}^{2+}$ seviyesinin artışına neden olur. Hücre içi yüksek $\mathrm{Ca}^{2+}$ seviyesi oksidatif fosforilasyonu uyararak ATP'nin daha da artmasina neden olur. ATP, doğrudan veya dolaylı olarak, cAMP veya $\mathrm{Ca}^{2+}$ aracılığıyla, PKA, PKB ve PKC gibi birkaç ERK1/2 efektörünü etkinleştirebilir. Aerobik metabolizmanın bir sonucu olarak ROS üretimi artarken, hem doğrudan hem de dolaylı olarak ERK1/2'in fosforilasyonu yoluyla çoğalma ve farklılaşma uyarılır. Eritroid proliferasyonunda ve farklılaşmasındaki artış, hücrelerin metabolik hızlarının artmasına, dolayısıyla hızlı ROS artışıyla giden bir pozitif geri bildirim döngüsüne neden olabilir (84).

\section{Eritrositlerde Oksidatif Strese Karşı Koruyucu Mekanizmalar}

\section{a) Antioksidan enzimler ve moleküller}

Eritrositler, mitokondrileri olmadığ 1 için oksidatif fosforilasyon yapamazlar (18). Enerji üretimi için glikoz, anaerobik glikolitik yol ile parçalanır ve sonunda laktat ortaya çıkar. Glikoliz ile üretilen $\mathrm{NADH}$, metHb'nin ana indirgeyici ajanıdır. NADH'ye bağl1, sitokrom $b_{5}$ redüktaz (CYB5R, methemoglobin redüktaz) enzimi tarafından katalizlenen reaksiyon ile metHb'deki +3 değerli demir +2 değere dönüştürülür (85). MetHb üretiminin arttığı koşullarda, yüksek NADH talebine bağlı olarak glikolizde artış meydana gelir (86).

$$
N A D H+H b\left(F e^{+3}\right) \stackrel{\text { CYB5R }}{\longrightarrow} N A D^{+}+H b\left(F e^{+2}\right)
$$

Glikoz, sadece glikoliz yolağında değil, aynı zamanda NADP'nin NADPH'ye indirgendiği pentoz fosfat yolunda da kullanılır (57). Glutatyon redüktaz (GR) enzimi NADPH'1 oksitlenmiş glutatyonun (glutatyon disülfit, GSSG) iki glutatyon (GSH) molekülüne indirgenmesi için kullanır.

$$
N A D P H+G S S G \stackrel{\mathrm{GR}}{\rightarrow} 2 \mathrm{GSH}+N A D P^{+}
$$

GSH, glutatyon döngüsünün önemli bir antioksidan molekülüdür ve GPx, glutaredoksin (GRX), glutatyon-S-transferaz (GST) gibi birkaç enzim tarafindan indirgeyici bir ajan olarak kullanılır $(29,87)$.

GPx'in biyokimyasal işlevi, lipit hidroperoksitlerini (ROOH) onların alkollerine, serbest hidrojen peroksidi de suya indirgemektir.

$$
\begin{gathered}
2 \mathrm{GSH}+\mathrm{H}_{2} \mathrm{O}_{2} \stackrel{\mathrm{GPx}}{\longrightarrow} \mathrm{GSSG}+2 \mathrm{H}_{2} \mathrm{O} \\
2 \mathrm{GSH}+\mathrm{ROOH} \stackrel{\mathrm{GPx}}{\longrightarrow} \mathrm{GSSG}+\mathrm{ROH}+\mathrm{H}_{2} \mathrm{O}
\end{gathered}
$$

Oksitlenmiş proteinlerdeki sistein kalıntılarını indirgemek için GRX ve Tiyoredoksin (TRx) sistemi olarak adlandırılan iki önemli yol vardır (88).

GRX, GR tarafindan sağlanan GSH ile nonenzimatik olarak indirgenir. Redükte GRX $[G R X=$ $\left.(\mathrm{SH})_{2}\right]$, okside proteinlerin sistein kalıntılarını indirgeyerek disülfür bağlarını koparır (87).

$$
[G R X=(S-S)]+2 G S H \rightarrow\left[G R X=(S H)_{2}\right]+G S S G
$$

$\left[G R X=(S H)_{2}\right]+[$ Protein $=(S-S)] \rightarrow[G R X=(S-S)]+\left[\right.$ Protein $\left.=(S H)_{2}\right]$

Trx, tiyoredoksin redüktaz (TrxR) enzimi tarafindan, NADPH'ın indirgeyici ajan olarak kullanıldığı bir reaksiyon ile indirgenir $(25,89)$. İndirgenmiş Trx'in iki önemli fonksiyonu vardır. Bunlardan ilki, okside proteinlerin sistein kalıntılarını indirgemek ve diğeri Prx için elektron donörü işlevi görmektir. Prx hidrojen peroksiti ve diğer hidroperoksitlerin indirgenmesini sağlar.

$$
\begin{gathered}
\text { NADPH }+[\operatorname{Trx}=(S-S)] \stackrel{\operatorname{TrxR}}{\longrightarrow}\left[\operatorname{Trx}=(S H)_{2}\right]+N A D P^{+} \\
{\left[\operatorname{Tr} x=(S H)_{2}\right]+[\text { Protein }=(S-S)] \rightarrow[\operatorname{Trx}=(S-S)]+\left[\text { Protein }=(S H)_{2}\right]} \\
{\left[\operatorname{Tr} x=(S H)_{2}\right]+[\operatorname{Prx}=(S-S)] \rightarrow[\operatorname{Trx}=(S-S)]+\left[\operatorname{Prx}=(S H)_{2}\right]} \\
{\left[\operatorname{Prx}=(S H)_{2}\right]+\mathrm{H}_{2} \mathrm{O}_{2} \rightarrow[\operatorname{Prx}=(S-S)]+2 \mathrm{H}_{2} \mathrm{O}}
\end{gathered}
$$

GST enzimi, elektrofilik ksenobiyotikleri (R-X, doğal yollarla üretilmeyen veya organizma içinde bulunması beklenmeyen kimyasal maddelerin genel adı) detoksifiye etmek için GSH'yi kullanır $(25,90)$. GST aktivitesi sonucu ksenobiyotikler ile GSH kompleks oluşturur. Böylece ksenobiyotiklerin kritik hücresel proteinler ve nükleik asitlerle etkileşimleri önlenir.

$$
(R-X)+G S H \stackrel{G S T}{\longrightarrow}(G S-R)+X H
$$


Süperoksit dismutaz (SOD), $\mathrm{O}_{2}^{--}$'i daha az toksik olan $\mathrm{H}_{2} \mathrm{O}_{2}$ 'ye dönüştüren enzimdir. Daha sonra katalaz (CAT), $\mathrm{H}_{2} \mathrm{O}_{2}$ 'yi su ve oksijene nötralize eder (25).

$$
\begin{gathered}
2 \mathrm{O}_{2}^{--}+2 \underset{\mathrm{H}^{+}}{\stackrel{\text { SOD }}{\longrightarrow}} \mathrm{H}_{2} \mathrm{O}_{2}+\mathrm{O}_{2} \\
2 \mathrm{H}_{2} \mathrm{O}_{2} \stackrel{\text { CAT }}{\longrightarrow} 2 \mathrm{HO}_{2}+\mathrm{O}_{2}
\end{gathered}
$$

Bunlara ilave olarak, eritrositler, membranlarını oksidatif hasara karşı korumak için, antioksidan vitaminler olan $\mathrm{C}$ ve $\mathrm{E}$ vitaminlerine büyük miktarda geçirgenlik gösterir $(40,43)$.

\section{b) Eritropoezde sitoprotektif mekanizmalar}

ROS'ların varlığında, hem üretim yolağındaki hız sinırlayıc1 enzim olan $\delta$-aminolevulinat sentaz2'nin aktivitesi azalırken, Prx aktivitesi artar (91). Prx esas olarak peroksitleri ve tiyolleri indirgeyen antioksidan bir enzimdir (86). Bununla beraber, bant-3'ü ve bununla ilişkili proteinleri oksidatif hasardan korumak için, bant-3'ün sitoplazmik alanına bağlanarak hücre membranına göç edebilir $(8,92,93)$. Hemikromlar, Prx'in bağlanma bölgelerini kapatarak bu göçü engeller (8). Prx, hemoglobinin katlanarak üç boyutlu hâle gelmesi işleminde moleküler bir şaperonu olarak işlev görürken aynı zamanda hemoglobinin denatürasyonunu önler $(94,95)$. Dahası serbest hemi yüksek afinite ile bağlayarak onun oksidatif etkilerini önler (91). Prx'in, hemoglobin ve karbonik anhidrazdan sonra, eritrosit stoplazmasında en bol bulunan üçüncü protein olması, onun eritrositler için kayda değer önemi olduğunun bir göstergesidir (96).

Eritrositlerde bulunan bir başka şaperon, alfahemoglobin stabilize edici proteindir (AHSP). AHSP serbest alfa-globin zincirlerini bağlayarak onların doğal yapılarını korur (97). $\beta$-globin yokluğunda ve oksidan stres varlığında, demirin redoks reaksiyonlarını katalizleyemeyeceği şekilde $\mathrm{HbA}$ yapısında değişiklikler meydana getirir $(98,99)$. $\quad \beta$-globin sentezinin bozulduğu hemoglobinopatilerde, beraberinde AHSP seviyeleri de azalmışsa, bu durumu daha da kötüleştirir (100).

Eritroid hücreler, bir taraftan eritrosit yönüne nihai farklılaşmayı sağlamak ve aynı zamanda apoptozdan kaçınmak için oksidatif stresin üstesinden gelmelidirler. Eritropoezde, eritroidler olgunlaşırken, hemoglobinizasyon sırasında bazı eritrositlerde apoptoz görülür. Bunun nedeni oksitleyici bir ajan olan demir ve hemin hücre içi konsantrasyonunun aniden artmasidır (101). ROS artışına bağlı bu ölümler, pentoz fospat yolu ile üretilen ve önemli bir indirgeyici ajan olan NADPH tarafindan büyük oranda engellenir $(57,102)$.

Protein translasyonunun hem ile düzenlenen inhibitörü (HRI) bir başka sitoprotektif mekanizmadır. Hem miktarı azaldığında globin yapımı HRI tarafindan baskılanır. Oksidatif stres koşullarında, hem seviyesinden bağımsız olarak da HRI aktivasyonu görülür (103). HRI, ökaryotik translasyon başlatma faktörü $2 \alpha^{\prime}$ yı (eIF2 $\alpha$ ) fosforile ederek, globin translasyonunu inhibe eder. Fosforile eIF $2 \alpha$, proteotoksisiteden kaçınmak için proteinlerin translasyonunu inhibe eder ve aynı zamanda bir stres yanıtı kaskadını başlatmak için ATF4 gibi seçici mRNA'ların translasyonunu arttırır (104). HRI/eIF2 $\alpha /$ ATF4 sinyal yolağının eritropoezde, özellikle hemoglobinizasyon aşamasında, oksidatif stresi azaltmak üzere aktif olduğu gösterilmiştir (105). HRI ile başlatılan sinyal yolağının yeterli derecede çalışmadığı durumlarda, etkisiz eritropoez görülür (106).

HRI/eIF2 $\alpha /$ ATF4 yoluna ek olarak, NRF2 ve FOXO3, iyi bilinen bir başka antioksidan koruyucu sinyal yoludur $(107,108)$. Hücre içi hem konsantrasyonu artığında, bir antioksidan transkripsiyon faktörü olan NRF2 sinyal yolunun aktivitesi artar (109). NRF2 sinyal yolu hem yıkımının hız sınırlayıcı enzimi olan hemoksijenaz1 'in (HO-1) ekspresyonunu artırır (110). Oksidatif stres koşullarında, HRI / eIF2 $\alpha$ / ATF4 yolu da HO1 'in ekspresyonunu artırır (105). HRI sadece hem miktarına göre globin sentezini düzenlemekle kalmaz, aynı zamanda HO-1 ekspresyonunu indükleyerek, hem seviyesini toksik seviyeye ulaşmadan azaltır (105). NRF2 ve ATF4'ün HO-1 ekspresyonunu artırmak üzere etkileşim halinde olduğu görülmektedir (111). Yukarıda bahsedilenlere ek olarak, NRF2 ve HRI/eIF2 $\alpha /$ ATF4 yolu, stres yanıtı sinyalini arttıran NADPH kinon oksidoredüktaz 1 (NQO1) ve GST gibi birkaç hedefe daha sahiptir $(104,112)$.

FOXO3'ün, eritropoezin bir ara aşamasında aktive olduğu ve terminal olgunlaşmaya kadar aktif kaldığı belirlenmiştir. FOXO3, asıl olarak fosfatidilinositol 3-kinaz (PI3K)/Akt sinyal yolunun kontrolü altındadır (107). Fosforile olmamış, inaktif formdaki FOXO3, çekirdekte bulunur ve hedef genlerin transkripsiyonunun devam etmesini sağlar. Eritropoetin ile PI3K/Akt yolunun aktivasyonu, FOXO3'ün fosforilasyonuna neden olur. $\mathrm{Bu}$ fosforilasyon, FOXO3'ün çekirdekten dışlanmasına ve böylece transkripsiyon aktivitesinin durmasına neden olur. FOXO3 ayrıca, ROS varlığında, küçük GTPaz Ral / JNK yolu ile de aktive olur (113). FOXO3'ün fosforilasyonu DNA hasarını onarmak veya apoptozu indüklemek için hücre döngüsü yavaşlatılır (114-117). Bu dönemde, SOD ve CAT gibi çeşitli antioksidan enzimlerin miktarı artarken, eritroid farklılaşmaya zaman sağlamak için eritroid öncüllerinin çoğalması inhibe olur $(107,118,119)$. FOXO3, eritroid çoğalmayı ve olgunlaşmayı oksidatif stres aracılı bir süreçle senkronize eder. Eritropoezde oksidatif stresin düzenlenmesi için FOXO3 gereklidir (107). Genetik olarak FOXO3 eksikliği etkisiz eritropoeze neden olur (107).

\section{c) Protein kalite kontrol yolakları}

Eritroid hücreler, protein kalite kontrol yolakları (PQC) olarak adlandirılan mekanizmalar yoluyla, zararlı olma potansiyeli olan kararsız proteinleri 
etkisizleştirir (120). PQC'nin artmış aktivitesi özellikle alfa-globülinlerin fazlaca arttığ1 hemoglobinopatilerde oldukça önemlidir (120). Kararsiz protein seviyelerinin hücrenin PQC kapasitesini aştığ 1 durumlarda, proteinlerin yanlış katlanması ve birikmesi hücrede toksisiteye ve bunun sonucu olarak etkisiz eritropoeze neden olabilir $(121,122)$.

Eritroid öncülleri, globin seviyelerinindeki olas1 dengesizlikleri, ubiquitin/proteozom sistemi (UPS) aracılı yıkım, otofaji veya 1sı şoku şaperonları gibi PQC yolaklariyla dengeleyebilir (121-124). Bu yolaklar, sadece $\alpha$-globinlerin yıkımını değil, aynı zamanda hücrenin çekirdek atımı işleminden önce sitoplazmasında bulundurduğu gereksiz proteinlerin yıkımını da sağlar (125).

Retikülosit aşamasında GATA-1 tarafından uyarılan otofaji sayesinde mitokondriler ve diğer organeller sitoplazmadan temizlenir (126). $\alpha$ Globülinlerin fazlaca arttığı hemoglobinopatilerde lizozomlar içinde globin agregatlarının olduğu tespit etmiştir (127). Bu durum makul miktarda $\alpha$-globinin, UPS yoluyla parçalandığını, daha yüksek miktarların ise çökelme eğiliminde olduğunu ve agrezom aracilı makro-otofaji yoluyla temizlendiğini göstermektedir (123). Agrezomlar, çözünmeyen proteinlerin PQC mekanizmaları ile etkileşime girdiği ve anormal proteinlerin yeniden katlaması, UPS aracılı yıkım veya otofaji için ayrı bir ortam sağlayan dinamik yapılardır (128).

\section{SONUÇ}

Çeşitli fizyolojik ve metabolik süreçlerde önemli rol oynaması ve canlıdan izole edilmesi diğer hücrelere kıyasla daha kolay olması nedeniyle, eritrositler bilimsel deneylerde sıkça kullanılan bir araç olmuştur. Eritrositlerde oksidatif stres mekanizmalarının ve bu oksidatif stresi alt eden antioksidan sistemlerin neler olduğunu konu eden çalışmalar uzun zamandır popülerliğini korumaktadır. $\mathrm{Bu}$ derlemede, daha önce yapılan çalışmalar 1şı̆̆ında, eritrositlerde oksidatif stres oluşumuna neden olan özgül mekanizmalar, oksidatif stresin meydana getirdiği değişiklikler ve oksidatif stresten koruyucu antioksidan sistemlerin neler olduğu kapsamlı şekilde gözden geçirilmiştir.

Özet olarak, hemoglobinin oksidatif denatürasyonu sonucu ortaya çıkan süperoksit radikalleri, bu radikallerin etkisizleştirilmesi sırasında ortaya çıkan hidrojen peroksitler ve yine hidrojen peroksitlerin neden olduğu hemoglobinden methemoglobin ve ferril hemoglobin oluşumuyla sonuçlanan kısır döngü; hemin yapısında bulunan demirin femton reaktifi olarak hidroksil radikalleri üretimine neden olması; hemikrom oluşumuyla sonuçlanan hemoglobin denatürasyonu ve serbest globulin artışı gibi olaylar eritrositlerin fonksiyonlarını devam ettirebilmesi için önemli bir yap1 olan hücre membranına zarar vererek onun yapısının bozulmasına ve eriptozla sonuçlanan olaylara neden olur. Olgun eritrositte, oksidatif stresten kaynaklanan hasarı en aza indirmek için sitoprotektif mekanizmalar mevcuttur. Hemoglobin ve hem için bir antioksidan enzim ve şaperon olan PRDX2, $\alpha$-globin için bir şaperon olan AHSP, strestepki genlerinin ekspresyonunu düzenleyen bir antioksidan transkripsiyon faktörü olan NRF2, antioksidan enzimlerin ekspresyonunu artıran ve terminal farklılaşma için önemli olan bir transkripsiyon faktörü olan FOXO3, stres yanıtı kaskatının başlatıcısı ve terminal olgunlaşma için önemli olan protein translasyon inhibitörü olan HRI / eIF2 $\alpha$ / ATF4 yolu ve PQC olarak bilinen $\alpha$-globin seviyelerinin dengesi için önemli olan UPS ve otofaji gibi yollar, eritrositlerin temel savunma mekanizmalarına örnek gösterilebilir. Bunlara ek olarak, çeşitli antioksidan enzimler (örneğin SOD, CAT) ve moleküller (örn. GSH, E ve C vitamini), ROS'ları nötralize etmek için eritrositlerde işlev görür.

Eritrositlerde, oksidatif stres ve antioksidan mekanizmalar bir denge içindedir. Dengenin oksidatif stres yönünde bozulmas1, eritrosit hücresinin yap1 ve işlevlerini olumsuz etkiler. $\mathrm{Bu}$ derlemede tartışılan biyolojik olayların iyi bilinmesi, eritrosit işlev bozukluğuyla giden birçok hastalığın patofizyolojisinin anlaşılmasını kolaylaştıracaktır.

\section{Kaynaklar}

1. Ray PD, Huang BW, Tsuji Y. Reactive oxygen species (ROS) homeostasis and redox regulation in cellular signaling. Vol. 24, Cellular Signalling. 2012. p. 981-90.

2. Bhattacharyya A, Chattopadhyay R, Mitra S, Crowe SE. Oxidative stress: An essential factor in the pathogenesis of gastrointestinal mucosal diseases. Physiol Rev. 2014;94(2):329-54.

3. Cho KJ, Seo JM, Kim JH. Bioactive lipoxygenase metabolites stimulation of NADPH oxidases and reactive oxygen species. Vol. 32, Molecules and Cells. 2011. p.1-5.

4. Amer J, Fibach E. Chronic oxidative stress reduces the respiratory burst response of neutrophils from betathalassaemia patients. Br J Haematol. 2005;129(3):435-41.

5. Davalli P, Mitic T, Caporali A, Lauriola A, D'Arca D. ROS, Cell Senescence, and Novel Molecular Mechanisms in Aging and Age-Related Diseases. Vol. 2016, Oxidative Medicine and Cellular Longevity. 2016.

6. Pandey KB, Rizvi SI. Markers of oxidative stress in erythrocytes and plasma during aging in humans. Oxid Med Cell Longev. 2010;3(1):2-12.

7. Kanczler JM, Millar TM, Bodamyali T, Blake DR, Stevens CR. Xanthine oxidase mediates cytokine-induced, but not hormone-induced bone resorption. Vol. 37, Free Radical Research. 2003. p. 179-87.

8. De Franceschi L, Bertoldi M, Matte A, Santos Franco S, Pantaleo A, Ferru E, et al. Oxidative stress and $\beta$-thalassemic erythroid cells behind the molecular defect. Oxidative Medicine and Cellular Longevity. 2013.

9. Pizzino G, Irrera N, Cucinotta M, Pallio G, Mannino F, Arcoraci V, et al. Oxidative Stress: Harms and Benefits for Human Health. Vol. 2017, Oxidative Medicine and Cellular Longevity. 2017.

10. Tan BL, Norhaizan ME, Liew WPP, Rahman HS. Antioxidant and oxidative stress: A mutual interplay in agerelated diseases. Vol. 9, Frontiers in Pharmacology. 2018. 
11. Elmas O, Erbas O, Yigitturk G. The efficacy of Aesculus hippocastanum seeds on diabetic nephropathy in a streptozotocin-induced diabetic rat model. Biomed Pharmacother. 2016;83:392-6.

12. Gokcimen A, Kocak A, Gulle K, Sutcu R, Elmas O, Caliskan $\mathrm{S}$, et al. The effect of allopurinol on rat liver and spleen tissues in a chronic hyperammonemia animal model. Saudi Med J. 2007;28(11):1648-53.

13. Elmas O, Elmas O, Caliskan S. Investigation of the oxidative effect of chronic hyperammonemia on the kidney and the possible protective effect of allopurinol. Ren Fail. 2011;33(1):61-5.

14. Elmas O, Elmas O, Aliciguzel Y, Simsek T. The relationship between hypertension and plasma allantoin, uric acid, xanthine oxidase activity and nitrite, and their predictive capacity in severe preeclampsia. J Obstet Gynaecol (Lahore). 2016;36(1):34-8

15. Aslan M, Canatan D. Modulation of redox pathways in neutrophils from sickle cell disease patients. Exp Hematol. 2008;36(11):1535-44.

16. Diez-Silva M, Dao M, Han J, Lim C-T, Suresh S. Shape and Biomechanical Characteristics of Human Red Blood Cells in Health and Disease. MRS Bull. 2010;35(5):382-8.

17. Shah S, Huang X, Cheng L. Concise Review: Stem CellBased Approaches to Red Blood Cell Production for Transfusion. Stem Cells Transl Med. 2014;3(3):346-55.

18. Matteucci E, Giampietro O. Electron Pathways through Erythrocyte Plasma Membrane in Human Physiology and Pathology: Potential Redox Biomarker? Biomark Insights. 2007;2:117727190700200.

19. Farid Y, Lecat P. Biochemistry, Hemoglobin Synthesis [Internet]. StatPearls. 2019.

20. Pascual-Ahuir A, Manzanares-Estreder S, Proft M. Pro- and Antioxidant Functions of the Peroxisome-Mitochondria Connection and Its Impact on Aging and Disease. Vol. 2017, Oxidative Medicine and Cellular Longevity. 2017.

21. Umbreit J. Methemoglobin - It's not just blue: A concise review. Vol. 82, American Journal of Hematology. 2007. p. 134-44.

22. Rifkind JM, Mohanty JG, Nagababu E. The pathophysiology of extracellular hemoglobin associated with enhanced oxidative reactions. Vol. 6, Frontiers in Physiology. 2015

23. Kanias T, Acker JP. Biopreservation of red blood cells - The struggle with hemoglobin oxidation. Vol. 277, FEBS Journal. 2010. p. 343-56.

24. Simoni J, Simoni G, Lox CD, Feola M. Reaction of human endothelial cells to bovine hemoglobin solutions and tumor necrosis factor. Artif Cells, Blood Substitutes, Biotechnol. 1994;22(3):777-87.

25. Van Zwieten R, Verhoeven AJ, Roos D. Inborn defects in the antioxidant systems of human red blood cells. Vol. 67, Free Radical Biology and Medicine. 2014. p. 377-86.

26. Bunn HF, Jandl JH. Exchange of heme among hemoglobins and between hemoglobin and albumin. J Biol Chem. 1968;243(3):465-75.

27. Nagababu E, Rifkind JM. Formation of fluorescent heme degradation products during the oxidation of hemoglobin by hydrogen peroxide. Biochem Biophys Res Commun. 1998;247(3):592-6.

28. Sadrzadeh SMH, Graf E, Panter SS, Hallaway PE, Eaton JW. Hemoglobin. A biologic Fenton reagent. J Biol Chem. 1984;259(23):14354-6.

29. Reiter RJ, Melchiorri D, Sewerynek E, Poeggeler B, Barlow- Walden L, Chuang J, et al. A review of the evidence supporting melatonin's role as an antioxidant. J Pineal Res. 1995;18(1):1-11.

30. Shalev O, Repka T, Goldfarb A, Grinberg L, Abrahamov A, Olivieri NF, et al. Deferiprone (L1) chelates pathologic iron deposits from membranes of intact thalassemic and sickle red blood cells both in vitro and in vivo. Blood. 1995;86(5):2008-13.

31. Balla J, Jacob HS, Balla G, Nath K, Eaton JW, Vercellotti GM. Endothelial-cell heme uptake from heme proteins: Induction of sensitization and desensitization to oxidant damage. Proc Natl Acad Sci U S A. 1993;90(20):9285-9.
32. Jeney V, Balla J, Yachie A, Varga Z, Vercellotti GM, Eaton JW, et al. Pro-oxidant and cytotoxic effects of circulating heme. Blood. 2002;100(3):879-87.

33. Wagener FADTG, Feldman E, De Witte T, Abraham NG. Heme Induces the Expression of Adhesion Molecules ICAM1, VCAM-1, and E Selectin in Vascular Endothelial Cells. Exp Biol Med. 1997;216(3):456-63.

34. Tracz MJ, Alam J, Nath KA. Physiology and pathophysiology of heme: Implications for kidney disease. Vol. 18, Journal of the American Society of Nephrology. 2007. p. 414-20.

35. George A, Pushkaran S, Konstantinidis DG, Koochaki S, Malik P, Mohandas N, et al. Erythrocyte NADPH oxidase activity modulated by Rac GTPases, PKC, and plasma cytokines contributes to oxidative stress in sickle cell disease. Blood. 2013;121(11):2099-107.

36. Balagopalakrishna C, Manoharan PT, Abugo OO, Rifkind JM. Production of superoxide from hemoglobin-bound oxygen under hypoxic conditions. Biochemistry. 1996;35(20):6393-8

37. Cao Z, Bell JB, Mohanty JG, Nagababu E, Rifkind JM. Nitrite enhances RBC hypoxic ATP synthesis and the release of ATP into the vasculature: A new mechanism for nitriteinduced vasodilation. Am J Physiol - Hear Circ Physiol. 2009;297(4):1494-503

38. Mohanty JG, Nagababu E, Rifkind JM. Red blood cell oxidative stress impairs oxygen delivery and induces red blood cell aging. Vol. 5 FEB, Frontiers in Physiology. 2014.

39. Barodka VM, Nagababu E, Mohanty JG, Nyhan D, Berkowitz DE, Rifkind JM, et al. New insights provided by a comparison of impaired deformability with erythrocyte oxidative stress for sickle cell disease. Blood Cells, Mol Dis. 2014;52(4):230-5.

40. May JM. Ascorbate function and metabolism in the human erythrocyte. Vol. 3, Frontiers in bioscience: a journal and virtual library. 1998

41. Nagababu E, Chrest FJ, Rifkind JM. Hydrogen-peroxideinduced heme degradation in red blood cells: The protective roles of catalase and glutathione peroxidase. Biochim Biophys Acta - Gen Subj. 2003;1620(1-3):211-7.

42. Nagababu E, Mohanty JG, Friedman JS, Rifkind JM. Role of peroxiredoxin-2 in protecting RBCs from hydrogen peroxide-induced oxidative stress. Free Radic Res. 2013;47(3):164-71.

43. Clemens MR, Waller HD. Lipid peroxidation in erythrocytes. Chem Phys Lipids. 1987;45(2-4):251-68.

44. Kuypers FA, de Jong K. The role of phosphatidylserine in recognition and removal of erythrocytes. Vol. 50, Cellular and molecular biology (Noisy-le-Grand, France). 2004. p. 147-58

45. Pries AR, Secomb TW, Gaehtgens P. Biophysical aspects of blood flow in the microvasculature. Vol. 32, Cardiovascular Research. 1996. p. 654-67.

46. Ibrahim HA, Fouda MI, Yahya RS, Abousamra NK, Abd Elazim RA. Erythrocyte phosphatidylserine exposure in $\beta$ thalassemia. Lab Hematol. 2014;20(2):9-14.

47. Kiefer CR, Snyder LM. Oxidation and erythrocyte senescence. Curr Opin Hematol. 2000;7(2):113-6.

48. Lang E, Lang F. Mechanisms and pathophysiological significance of eryptosis, the suicidal erythrocyte death. Vol. 39, Seminars in Cell and Developmental Biology. 2015. p. $35-42$.

49. Pantaleo A, Giribaldi G, Mannu F, Arese P, Turrini F. Naturally occurring anti-band 3 antibodies and red blood cell removal under physiological and pathological conditions. Vol. 7, Autoimmunity Reviews. 2008. p. 457-62.

50. Rachmilewitz EA, Weizer-Stern O, Adamsky K, Amariglio $\mathrm{N}$, Rechavi G, Breda $\mathrm{L}$, et al. Role of iron in inducing oxidative stress in thalassemia: Can it be prevented by inhibition of absorption and by antioxidants? In: Annals of the New York Academy of Sciences. 2005. p. 118-23.

51. Bordin L, Brunati AM, Donella-Deana A, Baggio B, Toninello A, Clari G. Band 3 is an anchor protein and a target for SHP-2 tyrosine phosphatase in human erythrocytes. Blood. 2002;100(1):276-82 
52. Mannu F, Arese P, Cappellini MD, Fiorelli G, Cappadoro M, Giribaldi G, et al. Role of hemichrome binding to erythrocyte membrane in the generation of band-3 alterations in $\beta$ thalassemia intermedia erythrocytes. Blood. 1995;86(5):2014-20.

53. Ferru E, Giger K, Pantaleo A, Campanella E, Grey J, Ritchie $\mathrm{K}$, et al. Regulation of membrane-cytoskeletal interactions by tyrosine phosphorylation of erythrocyte band 3. Blood. 2011;117(22):5998-6006.

54. Lutz HU, Nater M, Stammler P. Naturally occurring antiband 3 antibodies have a unique affinity for C3. Immunology [Internet]. 1993;80(2):191-6.

55. Kannan R, Labotka R, Low PS. Isolation and characterization of the hemichrome-stabilized membrane protein aggregates from sickle erythrocytes. Major site of autologous antibody binding. J Biol Chem. 1988;263(27):13766-73.

56. Harrison ML, Rathinavelu P, Arese P, Geahlen RL, Low PS. Role of band 3 tyrosine phosphorylation in the regulation of erythrocyte glycolysis. J Biol Chem. 1991;266(7):4106-11.

57. Beutler E. Red cell metabolism. A. Defects not causing hemolytic disease. B. Environmental modification. Biochimie. 1972;54(5-6):759-64.

58. Shinar E, Rachmilewitz EA, Lux SE. Differing erythrocyte membrane skeletal protein defects in alpha and beta thalassemia. J Clin Invest. 1989;83(2):404-10.

59. George A, Pushkaran S, Li L, An X, Zheng Y, Mohandas N, et al. Altered phosphorylation of cytoskeleton proteins in sickle red blood cells: The role of protein kinase C, Rac GTPases, and reactive oxygen species. Blood Cells, Mol Dis. 2010;45(1):41-5

60. Leonard SS, Harris GK, Shi X. Metal-induced oxidative stress and signal transduction. Vol. 37, Free Radical Biology and Medicine. 2004. p. 1921-42.

61. Omura T. Heme-thiolate proteins. Vol. 338, Biochemical and Biophysical Research Communications. 2005. p. 404-9.

62. Matarrese P, Straface E, Pietraforte D, Gambardella L, Vona R, Maccaglia A, et al. Peroxynitrite induces senescence and apoptosis of red blood cells through the activation of aspartyl and cysteinyl proteases. FASEB J. 2005;19(3):1-27.

63. Clementi ME, Giardina B, Colucci D, Galtieri A, Misiti F. Amyloid-beta peptide affects the oxygen dependence of erythrocyte metabolism: A role for caspase 3. Int J Biochem Cell Biol. 2007;39(4):727-35.

64. Zeuner A, Eramo A, Testa U, Felli N, Pelosi E, Mariani G, et al. Control of erythroid cell production via caspase-mediated cleavage of transcription factor SCL/Tal-1. Vol. 10, Cell Death and Differentiation. 2003. p. 905-13.

65. De Maria R, Zeuner A, Eramo A, Domenichelli C, Bonci D, Grignani F, et al. Negative regulation of erythropoiesis by caspase-mediated cleavage of GATA-1. Nature. 1999;401(6752):489-93.

66. Mandal D, Baudin-Creuza V, Bhattacharyya A, Pathak S, Delaunay J, Kundu M, et al. Caspase 3-mediated Proteolysis of the N-terminal Cytoplasmic Domain of the Human Erythroid Anion Exchanger 1 (Band 3). J Biol Chem. 2003;278(52):52551-8

67. Mandal D, Mazumder A, Das P, Kundu M, Basu J. Fas-, caspase 8-, and caspase 3-dependent signaling regulates the activity of the aminophospholipid translocase and phosphatidylserine externalization in human erythrocytes. J Biol Chem. 2005;280(47):39460-7.

68. Föller M, Harris IS, Elia A, John R, Lang F, Kavanagh TJ, et al. Functional significance of glutamate-cysteine ligase modifier for erythrocyte survival in vitro and in vivo. Cell Death Differ. 2013;20(10):1350-8.

69. Redding GS, Record DM, Raess BU. Calcium-Stressed Erythrocyte Membrane Structure and Function for Assessing Glipizide Effects on Transglutaminase Activation. Proc Soc Exp Biol Med. 1991;196(1):76-82.

70. Zipser Y, Piade A, Barbul A, Korenstein R, Kosower NS. $\mathrm{Ca} 2+$ promotes erythrocyte band 3 tyrosine phosphorylation via dissociation of phosphotyrosine phosphatase from band 3. Biochem J. 2002;368(1):137-44.

71. Burger P, Kostova E, Bloem E, Hilarius-Stokman P, Meijer $\mathrm{AB}$, van den Berg TK, et al. Potassium leakage primes stored erythrocytes for phosphatidylserine exposure and shedding of pro-coagulant vesicles. Br J Haematol. 2013;160(3):377-86.

72. Ney PA, Christopher MM, Hebbel RP. Synergistic effects of oxidation and deformation on erythrocyte monovalent cation leak. Blood. 1990;75(5):1192-8.

73. Willekens FLA, Werre JM, Groenen-Döpp YAM, Roerdinkholder-Stoelwinder B, De Pauw B, Bosman GJCGM. Erythrocyte vesiculation: A self-protective mechanism? Br J Haematol. 2008;141(4):549-56.

74. Barodka V, Mohanty JG, Mustafa AK, Santhanam L, Nyhan A, Bhunia AK, et al. Nitroprusside inhibits calcium-induced impairment of red blood cell deformability. Transfusion. 2014;54(2):434-44.

75. Olivieri O, De Franceschi L, Capellini MD, Girelli D, Corrocher R, Brugnara C. Oxidative damage and erythrocyte membrane transport abnormalities in thalassemias. Blood. 1994;84(1):315-20.

76. De Franceschi L, Ronzoni L, Cappellini MD, Cimmino F, Siciliano A, Alper SL, et al. K-CL co-transport plays an important role in normal and $\beta$ thalassemic erythropoiesis. Haematologica. 2007;92(10):1319-26.

77. Lang F, Busch GL, Ritter M, Völkl H, Waldegger S, Gulbins E, et al. Functional significance of cell volume regulatory mechanisms. Vol. 78, Physiological Reviews. 1998. p. 247306

78. Ribeil JA, Arlet JB, Dussiot M, Cruz Moura I, Courtois G, Hermine O. Ineffective erythropoiesis in $\beta$-thalassemia. Sci World J. 2013;2013.

79. Blouin MJ, De Paepe ME, Trudel M. Altered hematopoiesis in murine sickle cell disease. Blood. 1999;94(4):1451-9.

80. Angelucci E, Bai H, Centis F, Bafti MS, Lucarelli G, Ma L, et al. Enhanced macrophagic attack on $\beta$-thalassemia major erythroid precursors. Haematologica. 2002;87(6):578-83.

81. Centis F, Tabellini L, Lucarelli G, Buffi O, Tonucci P, Persini $\mathrm{B}$, et al. The importance of erythroid expansion in determining the extent of apoptosis in erythroid precursors in patients with $\beta$-thalassemia major. Blood. 2000;96(10):36249.

82. Dussiot M, Maciel TT, Fricot A, Chartier C, Negre O, Veiga $\mathrm{J}$, et al. An activin receptor IIA ligand trap corrects ineffective erythropoiesis in $\beta$-thalassemia. Nat Med. 2014;20(4):398407

83. Mathias LA, Fisher TC, Zeng L, Meiselman HJ, Weinberg $\mathrm{KI}$, Hiti AL, et al. Ineffective erythropoiesis in $\beta$-thalassemia major is due to apoptosis at the polychromatophilic normoblast stage. Exp Hematol. 2000;28(12):1343-53.

84. Leecharoenkiat A, Wannatung T, Lithanatudom P, Svasti S, Fucharoen S, Chokchaichamnankit D, et al. Increased oxidative metabolism is associated with erythroid precursor expansion in $\beta$ 0-thalassaemia/Hb E disease. Blood Cells, Mol Dis. 2011;47(3):143-57.

85. Percy MJ, Lappin TR. Recessive congenital methaemoglobinaemia: Cytochrome b5 reductase deficiency. Br J Haematol. 2008;141(3):298-308.

86. Ogasawara Y, Funakoshi M, Ishii K. Glucose metabolism is accelerated by exposure to t-butylhydroperoxide during NADH consumption in human erythrocytes. Blood Cells, Mol Dis. 2008;41(3):237-43.

87. Begas P, Liedgens L, Moseler A, Meyer AJ, Deponte M. Glutaredoxin catalysis requires two distinct glutathione interaction sites. Nat Commun. 2017;8

88. Hanschmann EM, Godoy JR, Berndt C, Hudemann C, Lillig $\mathrm{CH}$. Thioredoxins, glutaredoxins, and peroxiredoxinsmolecular mechanisms and health significance: From cofactors to antioxidants to redox signaling. Vol. 19, Antioxidants and Redox Signaling. 2013. p. 1539-605.

89. Arnér ESJ, Holmgren A. Physiological functions of thioredoxin and thioredoxin reductase. Vol. 267, European Journal of Biochemistry. 2000. p. 6102-9.

90. Mannervik B. The enzymes of glutathione metabolism: an overview. Vol. 15, Biochemical Society transactions. 1987. p. $717-8$.

91. de Franceschi L, Bertoldi M, de Falco L, Franco SS, Ronzoni $\mathrm{L}$, Turrini F, et al. Oxidative stress modulates heme synthesis and induces peroxiredoxin- 2 as a novel cytoprotective 
response in $\beta$-thalassemic erythropoiesis. Haematologica. 2011;96(11):1595-604

92. Matte A, Bertoldi M, Mohandas N, An X, Bugatti A, Brunati $\mathrm{AM}$, et al. Membrane association of peroxiredoxin-2 in red cells is mediated by the N-terminal cytoplasmic domain of band 3. Free Radic Biol Med. 2013;55:27-35.

93. Perrotta S, Borriello A, Scaloni A, De Franceschi L, Brunati AM, Turrini F, et al. The $\mathrm{N}$-terminal 11 amino acids of human erythrocyte band 3 are critical for aldolase binding and protein phosphorylation: Implications for band 3 function. Blood. 2005;106(13):4359-65.

94. Low FM, Hampton MB, Winterbourn CC. Peroxiredoxin 2 and peroxide metabolism in the erythrocyte. Vol. 10, Antioxidants and Redox Signaling. 2008. p. 1621-9.

95. Stuhlmeier KM, Kao JJ, Wallbrandt P, Lindberg $M$, Hammarström B, Broell $\mathrm{H}$, et al. Antioxidant protein 2 prevents methemoglobin formation in erythrocyte hemolysates. Eur J Biochem. 2003;270(2):334-41.

96. Harper VM, Oh JY, Stapley R, Marques MB, Wilson L, Barnes $\mathrm{S}$, et al. Peroxiredoxin-2 recycling is inhibited during erythrocyte storage. Antioxidants Redox Signal. 2015;22(4):294-307.

97. Yu X, Kong Y, Dore LC, Abdulmalik O, Katein AM, Zhou $S$, et al. An erythroid chaperone that facilitates folding of $\alpha-$ globin subunits for hemoglobin synthesis. J Clin Invest. 2007;117(7):1856-65.

98. Zhou S, Olson JS, Fabian M, Weiss MJ, Gow AJ. Biochemical fates of $\alpha$ hemoglobin bound to $\alpha$ hemoglobinstabilizing protein AHSP. J Biol Chem. 2006;281(43):32611-8

99. Feng L, Zhou S, Gu L, Gell DA, Mackay JP, Weiss MJ, et al. Structure of oxidized $\alpha$-haemoglobin bound to AHSP reveals a protective mechanism for haem. Nature. 2005;435(7042):697-701.

100.Kong Y, Zhou S, Kihm AJ, Katein AM, Yu X, Gell DA, et al. Loss of $\alpha$-hemoglobin-stabilizing protein impairs erythropoiesis and exacerbates $\beta$-thalassemia. J Clin Invest. 2004;114(10):1457-66.

101.Ghaffari S. Oxidative stress in the regulation of normal and neoplastic hematopoiesis. Vol. 10, Antioxidants and Redox Signaling. 2008. p. 1923-40.

102.Paglialunga F, Fico A, Iaccarino I, Notaro R, Luzzatto L, Martini G, et al. G6PD is indispensable for erythropoiesis after the embryonic-adult hemoglobin switch. Blood. 2004;104(10):3148-52.

103.Lu L, Han A-P, Chen J-J. Translation Initiation Control by Heme-Regulated Eukaryotic Initiation Factor 2alpha Kinase in Erythroid Cells under Cytoplasmic Stresses. Mol Cell Biol. 2001;21(23):7971-80.

104.Harding HP, Zhang Y, Zeng H, Novoa I, Lu PD, Calfon M, et al. An integrated stress response regulates amino acid metabolism and resistance to oxidative stress. Mol Cell. 2003;11(3):619-33.

105.Suragani RNVS, Zachariah RS, Velazquez JG, Liu S, Sun $\mathrm{CW}$, Townes TM, et al. Heme-regulated eIF2 $\alpha$ kinase activated Atf4 signaling pathway in oxidative stress and erythropoiesis. Blood. 2012;119(22):5276-84.

106.Han AP, Fleming MD, Chen JJ. Heme-regulated eIF2 $\alpha$ kinase modifies the phenotypic severity of murine models of erythropoietic protoporphyria and $\beta$-thalassemia. J Clin Invest. 2005;115(6):1562-70.

107. Marinkovic D, Zhang X, Yalcin S, Luciano JP, Brugnara C, Huber $\mathrm{T}$, et al. Foxo3 is required for the regulation of oxidative stress in erythropoiesis. $\mathrm{J}$ Clin Invest. 2007;117(8):2133-44.

108.Kawatani Y, Suzuki T, Shimizu R, Kelly VP, Yamamoto M. Nrf2 and selenoproteins are essential for maintaining oxidative homeostasis in erythrocytes and protecting against hemolytic anemia. Blood. 2011;117(3):986-96.

109. Alam J, Killeen E, Gong P, Naquin R, Hu B, Stewart D, et al. Heme activates the heme oxygenase- 1 gene in renal epithelial cells by stabilizing Nrf2. Am J Physiol - Ren Physiol. 2003;284(4 53-4).

110.Kitamuro T, Takahashi K, Ogawa K, Udono-Fujimori R, Takeda K, Furuyama K, et al. Bach1 functions as a hypoxia- inducible repressor for the heme oxygenase-1 gene in human cells. J Biol Chem. 2003;278(11):9125-33

111.He CH, Gong P, Hu B, Stewart D, Choi ME, Choi AMK, et al. Identification of activating transcription factor 4 (ATF4) as an Nrf2-interacting protein. Implication for heme oxygenase-1 gene regulation. J Biol Chem. 2001;276(24):20858-65.

112. Owusu-Ansah A, Choi SH, Petrosiute A, Letterio JJ, Huang AYC. Triterpenoid inducers of Nrf2 signaling as potential therapeutic agents in sickle cell disease: a review. Vol. 9, Frontiers of Medicine. 2015. p. 46-56.

113.Essers MAG, Weijzen S, De Vries-Smits AMM, Saarloos I, De Ruiter ND, Bos JL, et al. FOXO transcription factor activation by oxidative stress mediated by the small GTPase Ral and JNK. EMBO J. 2004;23(24):4802-12.

114.Martinez-Gac L, Marques M, Garcia Z, Campanero MR, Carrera AC. Control of Cyclin G2 mRNA Expression by Forkhead Transcription Factors: Novel Mechanism for Cell Cycle Control by Phosphoinositide 3-Kinase and Forkhead. Mol Cell Biol. 2004;24(5):2181-9.

115.Tran H, Brunet A, Grenier JM, Datta SR, Fornace AJ, DiStefano PS, et al. DNA repair pathway stimulated by the forkhead transcription factor FOXO3a through the Gadd45 protein. Science (80- ). 2002;296(5567):530-4.

116.Dijkers PF, Medema RH, Pals C, Banerji L, Thomas NSB, Lam EW-F, et al. Forkhead Transcription Factor FKHR-L1 Modulates Cytokine-Dependent Transcriptional Regulation of p27KIP1. Mol Cell Biol. 2000;20(24):9138-48.

117.Ghaffari S, Jagani Z, Kitidis C, Lodish HF, Khosravi-Far R. Cytokines and BCR-ABL mediate suppression of TRAILinduced apoptosis through inhibition of forkhead FOXO3a transcription factor. Proc Natl Acad Sci U S A. 2003;100(11):6523-8.

118. Nemoto S, Finkel T. Redox regulation of forkhead proteins through a p66shc-dependent signaling pathway. Science (80). 2002;295(5564):2450-2.

119.Kops GJPL, Dansen TB, Polderman PE, Saarloos I, Wirtz KWA, Coffer PJ, et al. Forkhead transcription factor FOXO3a protects quiescent cells from oxidative stress. Nature. 2002;419(6904):316-21.

120.Khandros E, Weiss MJ. Protein quality control during erythropoiesis and hemoglobin synthesis. Vol. 24, Hematology/Oncology Clinics of North America. 2010. p. 1071-88.

121.Shaeffer JR. ATP-dependent proteolysis of hemoglobin $\alpha$ chains in $\beta$-thalassemic hemolysates is ubiquitin-dependent. J Biol Chem. 1988;263(27):13663-9.

122. Vettore L, de Matteis MC, di Lorio EE, Winterhalter KH. Erythrocytic proteases: Preferential degradation of alpha hemoglobin chains. Acta Haematol. 1983;70(1):35-42.

123.Khandros E, Thom CS, D'Souza J, Weiss MJ. Integrated protein quality-control pathways regulate free $\alpha$-globin in murine $\beta$-thalassemia. Blood. 2012;119(22):5265-75.

124.Braverman AS, Lester D. Evidence for increased proteolysis in intact $\beta$ thalassemia erythroid cells. Hemoglobin. 1981;5(6):549-64

125.Etlinger JD, Goldberg AL. A soluble ATP dependent proteolytic system responsible for the degradation of abnormal proteins in reticulocytes. Proc Natl Acad Sci U S A. 1977;74(1):54-8.

126.Kang Y-A, Sanalkumar R, O'Geen H, Linnemann AK, Chang C-J, Bouhassira EE, et al. Autophagy Driven by a Master Regulator of Hematopoiesis. Mol Cell Biol. 2012;32(1):226-39.

127. Wickramasinghe SN, Bush V. Observations on the Ultrastructure of Erythropoietic Cells and Reticulum Cells in the Bone Marrow of Patients with Homozygous $\beta$ Thalassaemia. Br J Haematol. 1975;30(4):395-9.

128. Kopito RR. Aggresomes, inclusion bodies and protein aggregation. Vol. 10, Trends in Cell Biology. 2000. p. 52430. 